\title{
The influence of phytoestrogens or estrogens on the proliferation of the rat endocervical mucosa
}

\author{
(iD) Paulo Celso Franco ${ }^{1}$ \\ (iD) Ricardo Santos Simões ${ }^{2}$ \\ (1) Adriana Aparecida Ferraz Carbone/1 \\ (iD) Gisela Rodrigues da Silva Sasso \\ (iD) Rinaldo Florencio-Silva ${ }^{1}$ \\ (iD) Edmund Chada Baracat ${ }^{2}$ \\ (iD) Manoel Batista Castello Girão 3 \\ (iD) losé Maria Soares Júnior ${ }^{2}$ \\ (iD) Manuel de Jesus Simões ${ }^{1}$
}

1. Departamento de Morfologia e Genética - Escola Paulista de Medicina/Universidade Federal de São Paulo - EPM/Unifesp - São Paulo, SP, Brasil. 2. Departamento de Obstetrícia e Ginecologia - Faculdade de Medicina da Universidade de São Paulo - FMUSP - São Paulo, SP, Brasil. 3. Departamento de Ginecologia - Escola Paulista de Medicina/Universidade Federal de São Paulo - EPM/Unifesp - São Paulo, SP, Brasil.

http://dx.doi.org/10.1590/1806-9282.66.2.174

\section{SUMMARY}

INTRODUCTION: Although estrogen therapy is widely used against post-menopausal symptoms, it can present adverse effects, including endometrial cancer. Soy isoflavones are considered a possible alternative to estrogen therapy. However, there are still concerns whether isoflavones exert trophic effects on the uterine cervix.

OBJECTIVES: To evaluate the histomorphometric and immunohistochemical alterations in the uterine cervix of ovariectomized rats treated with soy isoflavones (Iso).

METHODS: Fifteen adult Wistar rats were ovariectomized (Ovx) and divided into three groups: Group I (Ovx), administered with vehicle solution; Group II (OVX-Iso), administered with concentrated extract of Iso (150 mg/kg) by gavage; and Group III (OVX-E2), treated with $17 \beta$-estradiol $(10 \mu \mathrm{g} / \mathrm{kg})$, subcutaneously. After 30 days of treatments, the uterine cervix was fixed in $10 \%$ formaldehyde and processed for paraffin-embedding. Sections were stained with Hematoxylin and eosin for morphological and morphometric studies or subjected to immunohistochemistry for detections of Ki-67 and vascular endothelial growth factor-A (Vegf-A). The data obtained were subjected to statistical analysis ( $p \leq 0.05)$.

RESULTS: We noted an atrophic uterine cervix in Gl, whereas it was more voluminous in Gll and even more voluminous in Glll. The thickness of the cervical mucosa was significantly higher in GIII, as compared to Gl and Gll. The cell proliferation (Ki-67) was signifcantly elevated in the estradiol and isoflavones treated groups, whereas Vegf-A immunoexpression was significantly higher in Glll, as compared to groups Gll and Gl.

CONCLUSIONS: Soy isoflavones cause less trophic and proliferative effects in the uterine cervix of rats as compared to estrogen. KEYWORDS: Cervix uteri. Isoflavones. Estrogens. Ovariectomy. Rats.

DATE OF SUBMISSION: 17-Jun-2019

DATE OF ACCEPTANCE: 29-Jul-2019

CORRESPONDING AUTHOR: Rinaldo Florencio da Silva

Department of Morphology and Genetics - Escola Paulista de Medicina/Universidade Federal de São Paulo - EPM/Unifesp-Brasil. Street address: Rua Botucatu, n 740 Edifício Lemos Torres -2. andar Vila Clementino, São Paulo - SP, Brasil - CEP: 04023-062

E-mail: rinaldohisto.cell@gmail.com 


\section{INTRODUCTION}

Postmenopause is characterized by a pronounced reduction in estrogen levels, which leads to vasomotor symptoms such as hot flashes and night sweats. These conditions can worsen the overall quality of life and, in particular, the quality of sleep by increasing sleep disturbances. Many women may concurrently become depressed, suffer from vaginal dryness, and lose bone mass. All of these changes may have a negative effect on women. In order to mitigate the negative outcomes of hypoestrogenism, hormone therapy is indicated. ${ }^{1-3}$ However, there are other negative consequences, including cardiovascular diseases, which appear upon late-onset hormone therapy (over 10 years after menopause) or after 60 years of age. ${ }^{4}$ Another concern is the breast cancer risk, which may increase with combined estrogen-progestin therapy. ${ }^{4,5}$ Hence, there is a demand for alternative therapies against postmenopausal symptoms.

Soy isoflavones have a chemical structure similar to that of estrogens, making it possible for the former to bind to estrogen receptors, especially the $\beta$ receptor. Such binding produces biological effects similar to those of estrogens but with less impact on the cardiovascular system and on breast tissue. ${ }^{6-8}$ Studies of the genital system have reported that isoflavones may increase the proliferation of both the vaginal ${ }^{9}$ and endometrial epithelia. ${ }^{10}$ Meanwhile, little is known about the effects of isoflavones on the cervical epithelium.

The cervical epithelium is divided into ectocervical and endocervical epithelia, with a transition region between them. ${ }^{11}$ It has been hypothesized that this transition region may be susceptible to develop cervical neoplasia due to human papillomavirus (HPV) infection. ${ }^{12}$ Thus, it is important to investigate substances that could show trophic effects in this region. Ford et al. ${ }^{13}$ reported trophic effects on the cervix following treatment with genistein, a soy isoflavone, and suggested an estrogenic action by these compounds. Nevertheless, there are still few data on cervical epithelial behavior, mainly on the endocervical epithelium. Thus, in this study, we assessed the effects of a concentrated soy isoflavone extract on the endocervix of ovariectomized rats.

\section{METHODS}

\section{Animals and study design}

This was a randomized controlled experimental study, evaluated and approved by the Research Ethics
Committee of the Universidade Federal de São Paulo Escola Paulista de Medicina (UNIFESP/EPM); project Number: 0136-12. All the experimental procedures were conducted following national and international guidelines of animal use and care.

The experiment was carried out on 15 EPM-1 Wistar (Rattus norvegicus albinus) female rats aged 95 days and weighing $\pm 227 \mathrm{~g}$ each, provided by the Centro de Desenvolvimento de Modelos Experimentais em Medicina e Biologia-CEDEME, UNIFESP/EPM. The rats were transported to the animal facility of the laboratory of Histology and Structural Biology of UNIFESP/ EPM. The animals were kept in cages (45x30x15cm) in an environment with controlled lighting and temperature (constant light/dark cycle of 12/12 hours and room temperature at $22^{\circ} \mathrm{C}$ ) and were given food and water ad libitum.

After one week of the adaptation period, vaginal smear tests for five consecutive days were performed in all rats to monitor their estrous cycle. Only rats with regular estrous cycles remained in the experiment. Thereafter, the animals were anesthetized (ketamine, $0.08 \mathrm{~mL} / 100 \mathrm{~g}$ of body weight; xylazine, 0.04 $\mathrm{mL} / 100 \mathrm{~g}$ of body weight) and subsequently subjected to bilateral ovariectomy (Ovx).

In order to recover from Ovx surgery and ensure estrogen depletion, a period of twenty-one days after Ovx was adopted; the animals were then randomly divided into three groups, as follows: Group I (Ovx) - administered with $0.1 \mathrm{~mL}$ of a vehicle solution of propylene glycol (Sinthy ${ }^{\circledast}$ - São Paulo, Brasil) by gavage; Group II (Ovx-Iso) - administered with 150 mg/kg of a concentrated extract of soy isoflavones, diluted in 0.1 mL of propylene glycol, by gavage. Group III (Ovx-E2) -subcutaneous administration of $10 \mu \mathrm{g} / \mathrm{kg}$ of $17 \beta$-estradiol (Sigma-Aldrich Chemicals, Oakville, ON, Canada) diluted in corn oil.

The soy extract used in this study was concentrated and enriched with isoflavones (Novasoy ${ }^{\circledR}$, Archer Daniels Midland, Decatur, IL, EUA) with the following proportions: 40\% of total isoflavones (genistein, daidzein, and glycitein at a ratio of 1.3:1:0.3, respectively), $7 \%$ to $12 \%$ of proteins, $4 \%$ of ashes, $6 \%$ of humidity, and the remaining $41 \%$ was made up of soy phytocomponents. Treatments lasted for 30 consecutive days. No deaths were reported throughout the experimental period.

Material collection and histological processing

After treatment, the animals were anesthetized with ketamine $(0.08 \mathrm{~mL} / 100 \mathrm{~g}$ of body weight) and 
xylazine (0.04/100g of body weight) and euthanized by decapitation using an appropriate rodent guillotine. Subsequently, a laparotomy was performed to visualize the genital organs and collect the cervices. The cervices were then were fixed in $10 \%$ formaldehyde (phosphate buffer, $\mathrm{pH} 7.2,0.1 \mathrm{M}$ ) for 24 hours and subsequently processed for paraffin embedding, which was carried out in such a way to obtain longitudinal sections of the cervical region (Figure 1).

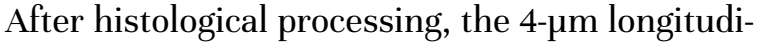
nal sections (Minot Leica RM2035 microtome) were stained with hematoxylin and eosin (H.E) for morphological and histomorphometric analyses or subjected to immunohistochemistry. Photomicrographs of the cervical sections were documented using a light microscope (Axiolab Standard 20, Carl Zeiss) coupled with a high-resolution video camera (AxionCam, Carl Zeiss) and subsequently underwent histomorphometric analysis.

\section{Histomorphometry of the cervix}

The histomorphometric evaluation was carried out with an image capture system, and the resulting images were analyzed using the Axiovision 4.8 REL (Carl Zeiss) software. Measurements were performed with 2.5x objective lenses for assessment of cervical thickness and 10x objective lenses for evaluation of the glandular area.

For each animal, five sections with 80- $\mu$ m intervals between them were made in order to analyze the following parameters: a) epithelial thickness, measurements were taken from the upper margin (luminal

FIGURE 1. DIAGRAM (A1) AND A LONGITUDINAL HISTOLOGICAL SECTION STAINED WITH H.E (A2) SHOWING THE REGION OF INTEREST. NOTE THAT THE REGION OF INTEREST WAS ESTABLISHED IN THE MIDREGION OF THE UTERINE CERVIX NAMED AS "A".

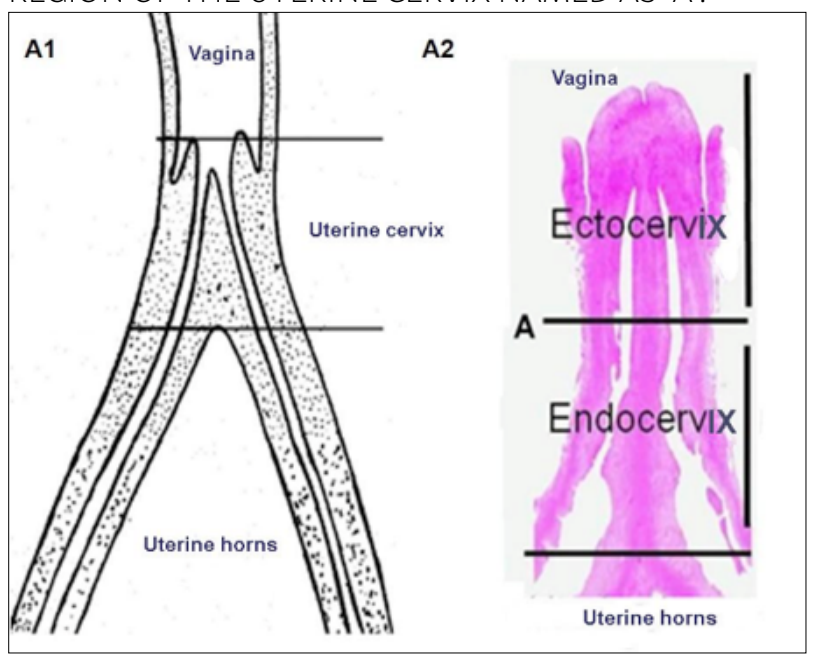

border) of the cervical epithelium outward in eight distinct regions of the endocervix, which were averaged to obtain a mean expressed in $\mu \mathrm{m}$; b) glandular area, the space occupied by the "glands" was outlined to cover an area up to $500 \mathrm{~mm}^{2}$ of the cervix in two semi-serial sections. The areas were added up and expressed in $\mathrm{mm}^{2}$.

\section{Immunohistochemical method}

After the sections were deparaffinized and hydrated, endogenous peroxidase activity was blocked with 3\% $\mathrm{H} 2 \mathrm{O} 2$ for 10 minutes. Next, the sections underwent antigen retrieval in a steam cooker with 10-mM sodium citrate buffer solution (pH6.0) for 1 hour. After cooling, the sections were washed with phosphate-buffered saline (PBS) and incubated with 4\% bovine serum albumin (BSA) for 20 minutes to block unspecified protein sites. Subsequently, the sections were incubated overnight with rabbit monoclonal primary antibodies (anti-Ki-67 or anti-Vegf-A, Spring, Bioscience, CA, USA) diluted at 1/200 and 1/300, respectively, in a humidity chamber at $4^{\circ} \mathrm{C}$. For negative controls, the primary antibodies were replaced by non-immune serum. Afterward, the sections were washed in PBS and incubated in a streptavidin-biotinylated secondary antibody (Dako, Denmark) for 30 minutes. After the washes, reactions were revealed with 3,3-diaminobenzidine (DAB) (Dako, Denmark), counterstained with Harris hematoxylin, and mounted using a permanent mounting medium (Entellan ${ }^{\circ}$ ). A brownish color in the nuclei for Ki-67 and the cell border region or the cell cytoplasm for Vegf-A was adopted as a standard of positivity.

The slides were examined under a light microscope with a 10x objective lens (Axiolab Standard 20, Carl Zeiss) coupled with a high-resolution video camera (AxioCam, Carl Zeiss). The percentage of Ki67-positive cells was calculated in each section; at least 500 cells per animal were counted, and a mean was calculated for each rat in every experimental group. Meanwhile, the immunoreactivity for Vegf-A was assessed through a semiquantitative scoring system $(\mathrm{H})$ as previously reported $^{6}$ and validated in our laboratory by Carbonel et al. ${ }^{7}$. Accordingly, a score of 0 was considered negative immunoreactivity, whereas positive immunoreactivities received scores from 1 to 3 according to the intensity of immunoreactivity.

\section{Statistical analysis}

The results were expressed as mean \pm standard deviation (SD). A comparison of the groups was made 
with the Kruskal-Wallis test followed by the Dunn test. The level of significance for the rejection of the null hypothesis was $\mathrm{p} \leq$ 0.05. Graph Pad Prism 5.0 (San Diego, CA, USA) software was used for every test.

\section{RESULTS}

Morphological analysis

The endocervix from GI (Ovx) was covered by cuboidal epithelium with a reduction in crypts lined with the same type of epithelium as in the other two groups. The endocervix from GIII (Ovx-E2) displayed a considerably thicker epithelium of the cervical mucosa than the other two groups. The epithelium itself showed signs of proliferation attested by mitosis and stratification, whereas the lamina propria had abundant crypts. The endocervix of all rats from GII (Ovx-Iso) exhibited greater signs of proliferation than that from GI, and columnar epithelium with a few areas of stratification was noticed. The histological pattern of one rat from GII was similar to that of GI. (Table 1, Figure 2).

\section{Histomorphometry of the cervical mucosa}

The endocervical mucosa was significantly thicker in GIII (Ovx-E2) than in GI (Ovx) and GII. Meanwhile, the glandular area in GIII (Ovx-E2) was considerably smaller than that in GI (Ovx) and GII (Ovx-Iso). Moreover, the endocervical mucosa in GI and GII presented a similar size. (Table 1, Figure 2).

Immunohistochemical detection of $\mathrm{Ki}-67$ and Vegf-A

The percentage of Ki-67-positive cells was significantly higher in GII (Ovx-Iso) and GIII (Ovx-E2) than in GI. However, this percentage was more noticeable
FIGURE 2. PHOTOMICROGRAPHS OF HISTOLOGICAL SECTIONS OF UTERINE CERVIX PORTIONS OF UTERI OF RATS STAINED WITH H.E (A - C), OR SUBJECTED TO IMMUNOHISTOCHEMISTRY AND COUNTERSTAINED WITH HARRIS' HEMATOXYLIN FOR THE DETECTION OF KI-67 (D - F) AND VEGF-A ( $G$ - I). NOTE GREATER THICKNESS OF THE EPITHELIUM OF THE ENDOCERVICAL MUCOSA (ASTERISKS) IN THE GII GROUP (OVX-ISO) (B), WHICH IS MORE EVIDENT IN THE GIII (OVX-E2) (C) AS COMPARED TO GI (OVX) (A). LARGER AREA OCCUPIED BY "GLANDS" (ARROWS) CAN ALSO BE SEEN IN GI (A) AND GII (B) AS COMPARED TO GIII (C). A HIGHER IMMUNOREACTIVITY (ARROWS) TO KI-67 (F) AND VEGF-A (I) CAN ALSO BE NOTICED IN THE GIII GROUP (OVX-E2), WHEN COMPARED TO GI (OVX) $(D, G)$ AND GII (E, H ). BARS: $50 \mu M$

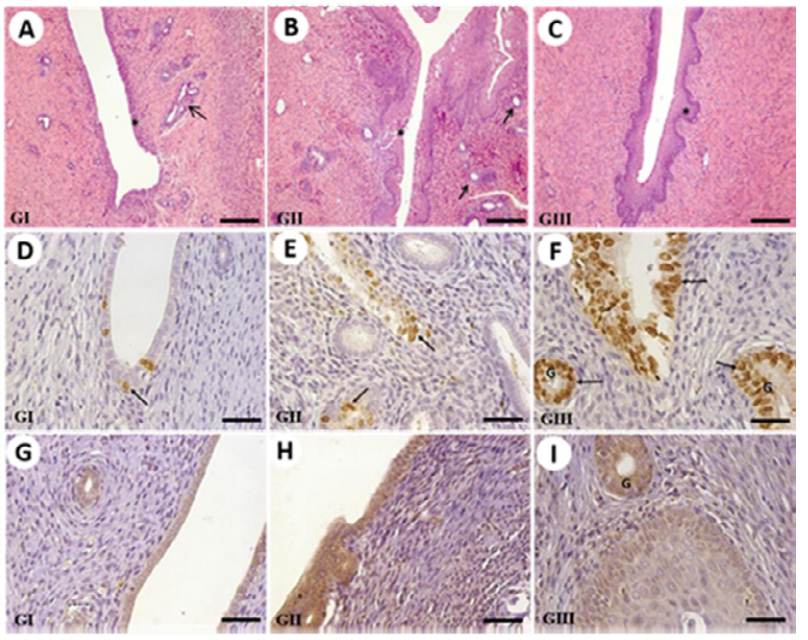

in GIII. Furthermore, Vegf-A immunoreactivity was significantly greater in GIII (Ovx-E2) than in GII (OvxIso) and GI (Ovx). (Table 1, Figure 2).

\section{DISCUSSION}

The concern about hormone therapy was the consequence of the study published by WHI (Women's Health Initiative) in 2002, in which they reported that combined hormone therapy using estrogens

TABLE 1. DATA EXPRESSED AS MEAN \pm STANDARD DEVIATION. ABBREVIATIONS: TEM = THICKNESS OF THE ENDOCERVICAL MUCOSA; GA = "GLANDULAR" AREA; CE = CERVICAL EPITHELIUM; GE = "GLANDULAR" EPITHELIUM.

\begin{tabular}{|c|c|c|c|}
\hline \multicolumn{4}{|c|}{ GROUPS } \\
\hline Parameters & Gl (Ovx) & GII (Ovx-Iso) & GIII (Ovx-E2) \\
\hline TEM & $360.30 \pm 11.40$ & $400.40 \pm 23.90^{*}$ & $584.70 \pm 33.80^{* \star}$ \\
\hline GA & $28.60 \pm 2.40$ & $24.40 \pm 2.50$ & $17.80 \pm 6.40^{*}$ \\
\hline Ki67/CE (\%) & $1.40 \pm 0.640$ & $4.60 \pm 1.60^{*}$ & $14.80 \pm 1.40^{\star \star}$ \\
\hline Ki67/GE (\%) & $2.46 \pm 1.60$ & $6.12 \pm 2.80^{*}$ & $12.18 \pm 1.16^{\star *}$ \\
\hline Vegf-A (Scores) & $1.80 \pm 0.37$ & $2.01 \pm 0.04$ & $2.90 \pm 0.15^{\star}$ \\
\hline
\end{tabular}


and progestogens correlated with breast cancer ${ }^{4}$. Therefore, some investigators started looking for options to ameliorate the symptoms of menopause. In fact, isoflavones became an alternative therapy for treating postmenopausal women with symptoms of hypoestrogenism.

Isoflavones are structurally similar to endogenous estrogens because they exhibit a phenolic ring with a hydroxyl radical in carbon ${ }^{3}$. Such a structure grants them a selective binding ability showing a strong affinity for alpha and beta estrogen receptors. ${ }^{13,14}$ These compounds have been found to have the same beneficial effects as estrogen therapy against menopausal symptoms but without the side effects ${ }^{15}$. Although the effects of isoflavones are reported to be weaker than those of endogenous estrogens, the impact of isoflavones on the cervix has not been explored so far ${ }^{16}$. In our results, soy isoflavones administration exhibited some trophic effects on the uterine cervical, but it was weaker when compared to estrogen, indicating that isoflavones produced less proliferative effects on the cervix of rats than estrogens.

In fact, we observed a thicker cervical mucosa epithelium in the groups treated with estrogens and isoflavones in contrast to the animals treated with the vehicle. Nonetheless, besides exhibiting the thickest epithelium, the estrogen-treated group showed the highest percentage of Ki-67-positive cells. Ki-67 is a nuclear marker of cell proliferation, and it is expressed in all of the cell cycle phases, except in GO. ${ }^{7,16-20}$ Therefore, our results indicate that the thicker cervical mucosa seen in GIII was the result, at least in part, of the increased rate of cell proliferation. On the other hand, it is worth emphasizing that although isoflavones exhibited a trophic effect on the thickness of the cervical mucosa, this effect was significantly smaller than that exerted by estrogens.
This suggests that the estrogenic activity of isoflavones is weaker in the endocervical region when compared to estrogens. In fact, isoflavone activity is 500 to 1000 times less potent than that of endogenous estrogens. ${ }^{21}$

Our data suggest that isoflavones exert a proliferative effect on the ectocervix, similar to what has been previously reported about the vaginal epithelium and endocervix. These descriptions are, in turn, similar to what occurs in the cervix. ${ }^{22}$ Thus, patients with chronic diseases such as HPV must receive special care to prevent their reactivation, which could be triggered by isoflavone-induced tissue proliferation..$^{23-25}$

\section{CONCLUSION}

In conclusion, our results show that isoflavones have trophic and proliferative effects on rat endocervix; however, these effects are less potent than those produced by estrogens.

\section{Conflict of interest}

The authors declare no conflict of interest in relation to this paper.

\section{Author Contributions}

Conceptualization, ${ }^{1}$ P.C.F, ${ }^{1}$ R.S.S., ${ }^{1}$ A.A.F.C., ${ }^{2}$ E.C.B., and ${ }^{1}$ M.J.S; J.M.S.J Funding acquisition, M.J.S., A.A.F.C., E.C.B., Resources, M.J.S., Execution of experiment, P.C.F., 'R.F-S., G.R.S.S.; A.A.F.C; Data collection, P.C.F., R.F-S., G.R.S.S.; A.A.F.C.; Data analysis, ${ }^{1}$ P.C.F, ${ }^{1}$ R.S.S., ${ }^{1}$ A.A.F.C., G.R.S.S., R.F-S ${ }^{2}$ E.C.B, and ${ }^{1}$ M.J.S.; Writing-original draft, P.C.F., A.A.F.C., R.FS., Writing-review \& editing, R.S.S., A.A.F.C., M.J.S., R.F-S., E.S.C. and ${ }^{2}$ J.M.S.J; Supervision, M.J.S; Project Administration, P.C.F., and M.J.S.

\section{RESUMO}

INTRODUÇÃO: Embora a terapia estrogênica seja amplamente utilizada contra sintomas pós-menopausais, ela pode apresentar efeitos adversos, incluindo câncer de mama e endometrial. Assim, as isoflavonas da soja são consideradas uma alternativa possível à terapia estrogênica. No entanto, ainda há controvérsias se estes compostos exercem efeitos tróficos significativos no colo do útero.

OBJETIVOS: Avaliar as alterações histomorfométricas e imuno-histoquímicas no colo do útero de ratas ovariectomizadas tratadas com isoflavonas da soja (iso).

MÉTODOS: Quinze ratas Wistar adultas foram ovariectomizadas bilateralmente (Ovx) e separadas em três grupos: Grupo I (Ovx) - veículo (propilenoglicol); Grupo II (Ovx-Iso) - receberam extrato concentrado de Iso (150 mg/kg) e Grupo III (Ovx-E2) - tratado com 17ß-estradiol $(10 \mu \mathrm{g} / \mathrm{kg})$; as soluções foram administradas via gavagem por 30 dias consecutivos. Posteriormente, os colos uterinos foram retirados, fixados em formaldeído a 10\% tamponado e processados para inclusão em parafina. Cortes $(4 \mu \mathrm{m})$ foram coradas com hematoxilina e eosina para estudo morfológico e morfométricos, enquanto outros foram submetidos à imuno-histoquímica para detecção de Ki-67 e do fator de crescimento endotelial vascular-A (Vegf-A). Os dados obtidos foram submetidos à análise estatística $(p \leq 0,05)$. 
RESULTADOS: Observamos a presença de colo uterino atrófico no Gl (Ovx), sendo este mais volumoso no Gll (Ovx+lso) e ainda mais volumoso no GIII (Ovx+E2). A espessura da mucosa cervical foi significativamente maior no GIII (Ovx-E2), em comparação ao Gl (Ovx) e ao Gll (Ovx-Iso). A proliferação celular (Ki-67) foi significativamente mais elevada nos grupos tratados com estradiol e isoflavonas, enquanto a imunoexpressão de Vegf-A foi significativamente maior no GIII (Ovx-E2), em comparação ao Gll (Ovx-Iso) e ao GI (Ovx-E2).

CONCLUSÕES: As isoflavonas da soja causam menos efeitos tróficos e proliferativos no colo do útero de ratas em comparação ao estrogênio. PALAVRAS-CHAVE: Colo do útero. Isoflavonas. Estrogênios. Ovariectomia. Ratos.

\section{REFERENCES}

1. Avis NE, Legault C, Russell G, Weaver K, Danhauer SC. Pilot study of integral yoga for menopausal hot flashes. Menopause. 2014;21(8):846-54.

2. Mirkin S, Amadio JM, Bernick BA, Pickar JH, Archer DF. $17 \beta$-Estradiol and natural progesterone for menopausal hormone therapy: REPLENISH phase 3 study design of a combination capsule and evidence review. Maturitas. 2015;81(1):28-35.

3. North American Menopause Society. The 2012 hormone therapy position statement of: the North American Menopause Society. Menopause. 2012;19(3):257-71.

4. Rossouw JE, Anderson GL, Prentice RL, LaCroix AZ, Kooperberg C, Stefanick $M L$, et al; Writing Group for the Women's Health Initiative Investigators. Risks and benefits of estrogen plus progestin in healthy postmenopausal women: principal results from the Women's Health Initiative randomized controlled trial. JAMA. 2002;288(3):321-33.

5. Davis R, Batur P, Thacker HL. Risks and effectiveness of compounded bioidentical hormone therapy: a case series. J Womens Health (Larchmt). 2014;23(8):642-8.

6. Maae E, Nielsen M, Steffensen KD, Jakobsen EH, Jakobsen A, Sørensen FB. Estimation of immunohistochemical expression of VEGF in ductal carcinomas of the breast. J Histochem Cytochem. 2011;59(8):750-60.

7. Carbonel AA, Baracat MC, Simões RS, Simões MI, Baracat EC, Soares IM Jr. The soybean concentrated extract proliferates the vagina of adult rats. Menopause. 2011;18(1):93-101.

8. Messina M. Soybean isoflavones warrant greater consideration as a treatment for the alleviation of menopausal hot flashes. Womens Health (Lond). 2014;10(6):549-53.

9. Aso T, Uchiyama S, Matsumura Y, Taguchi M, Nozaki M, Takamatsu K, et al. A natural S-equol supplement alleviates hot flushes and other menopausal symptoms in equol nonproducing postmenopausal Japanese women. Womens Health (Larchmt). 2012;21(1):92-100.

10. Jenks BH, Iwashita S, Nakagawa Y, Ragland K, Lee J, Carson WH, et al. A pilot study on the effects of $S$-equol compared to soy isoflavones on menopausal hot flash frequency. I Womens Health (Larchmt). 2012;21(6):674-82.

11. Wu AH, Koh WP, Wang R, Lee HP, Yu MC. Soy intake and breast cancer risk in Singapore Chinese Health Study. Br J Cancer. 2008;99(1):196-200.

12. Thurman AR, Yousefieh N, Chandra N, Kimble T, Asin S, Rollenhagen C, et al. Comparison of mucosal markers of human immunodeficiency virus susceptibility in healthy premenopausal versus postmenopausal women. AIDS Res Hum Retroviruses. 2017;33(8):807-19.
13. Ford JA Jr, Clark SG, Walters EM, Wheeler MB, Hurley WL. Estrogenic effects of genistein on reproductive tissues of ovariectomized gilts. J Anim Sci. 2006;84(4):834-42.

14. Molla MD, Hidalgo-Mora II, Soteras MG. Phytotherapy as alternative to hormone replacement therapy. Front Biosci (Schol Ed). 2011;3(1):191-204.

15. Carbonel AA, Calió ML, Santos MA, Bertoncini CR, Sasso GS, Simões RS, et al. Soybean isoflavones attenuate the expression of genes related to endometrial cancer risk. Climacteric. 2015;18(3):389-98.

16. Quaas AM, Kono N, Mack WJ, Hodis HN, Felix IC, Paulson RI, et al. Effect of isoflavone soy protein supplementation on endometrial thickness, hyperplasia, and endometrial cancer risk in postmenopausal women: a randomized controlled trial. Menopause. 2013;20(8):840-4.

17. Santell RC, Chang YC, Nair MG, Helferich WG. Dietary genistein exerts estrogenic effects upon the uterus, mammary gland and the hypothalamic/ pituitary axis in rats. J Nutr. 1997;127(2):263-9.

18. Wood CE, Register TC, Franke AA, Anthony MS, Cline JM. Dietary soy isoflavones inhibit estrogen effects in the postmenopausal breast. Cancer Res. 2006;66(2):1241-9.

19. Gerdes J, Lemke H, Baisch H, Wacker HH, Schwab U, Stein H. Cell cycle analysis of a cell proliferation-associated human nuclear antigen defined by the monoclonal antibody Ki-67. J Immunol. 1984;133(4):1710-5.

20. Brown DC, Gatter KC. Monoclonal antibody Ki-67: its use in histopathology. Histopathology. 1990;17(6):489-503.

21. Setchell KD, Cassidy A. Dietary isoflavones: biological effects and relevance to human health. J Nutr. 1999;129(3):758S-67S.

22. Francisco AM, Carbonel AF, Simões RS, Soares JM Jr, Baracat EC, Haidar MA. Do extracts of oral soybean augment the trophic effect of estrogen on the rat uterus? Climacteric. 2013;16(1):161-8.

23. Batra P, Sharma AK. Anti-cancer potential of flavonoids: recent trends and future perspectives. 3 Biotech. 2013;3(6):439-59.

24. Ghaemi A, Soleimanjahi H, Razeghi S, Gorji A, Tabaraei A, Moradi A, et al. Genistein induces a protective immunomodulatory effect in a mouse model of cervical cancer. Iran J Immunol. 2012;9(2):119-27.

25. Carbonel AAF, Lima PDA, Lim J), Fuchs LFP, Paiotti APR, Sasso GRDS, et al. The effects of soybean isoflavones and $17 \beta$-estradiol in uterus and mammary glands of diabetic rat models. Gynecol Endocrinol. 2018;34(4):314-9. 